\title{
Formoterol Fumarate
}

National Cancer Institute

\section{Source}

National Cancer Institute. Formoterol Fumarate. NCI Thesaurus. Code C47540.

The fumarate salt form of formoterol, a long-acting and selective sympathomimetic beta-receptor agonist with bronchodilator activity. Formoterol fumarate binds beta 2 adrenergic receptors in bronchial smooth muscle and stimulates intracellular adenyl cyclase, thereby increasing the production of cyclic adenosine monophosphate (CAMP). Increased cAMP levels cause relaxation of bronchial smooth muscle, improve mucociliary clearance and reduce mediator substance release in inflammatory cells, especially from mast cells. ( $\mathrm{NCl05)}$ 